\title{
Adequate Food, Adequate Parenting? Critical Insights on Family Law (and Justice) and Parenthood Through Food
}

\author{
Patrícia Branco \\ Center for Social Studies, University of Coimbra, Portugal
}

\begin{abstract}
The links between food, families and the law seem to be particularly strong in what concerns dietary issues, parental food choices and the best interests of the child. In such a framework, I will examine some recent decisions that have been pronounced by Italian courts having to decide disputes involving such questions in relation to alternative food choices. My claim, drawing on Canguilhem, is that some of these decisions seem to point towards an imposition to normalise food practices and familial behaviours: children and parents are to be educated towards food practices that are seen as in accord with social normativity (normal) and avoid those considered as deviant (pathological).
\end{abstract}

Keywords: Sociology of family law; food; court decisions; parental responsibilities; best interests of the child; normality and normativity.

\section{Introduction}

Law is not only transmitted from generation to generation through representations of precedent, ruling and authority. ${ }^{1}$ It is also transmitted at the dining table, direct to our stomachs and minds. ${ }^{2}$ Hence, food can be seen as an important means through which identities (class, ethnic, familial and ethical) are articulated and knotted, and where power dynamics and (social, economic and gender) inequalities are replicated. ${ }^{3}$

Consequently, food is more than just food: production, supply and cooking of food are rooted in sociocultural narratives with reference to politics, the law and social practices and norms. ${ }^{4}$ Thus, we eat what our cultures (and the globalisation of culture), parents and peers deem fit to eat. We eat what our geography allows us to eat. We eat what the market and food agrotechnology (with the industrialisation of production and distribution) have predisposed us to eat. We eat what our income permits us to eat (not only in terms of amounts but also the kinds of foods). We eat what our policymakers and health authorities advise us to eat. However, increasingly we eat, or do not eat, what food activists and influencers consider ethically fit for consumption. Further, in many cases, courts have decided on these matters too, particularly regarding children's diets.

\footnotetext{
${ }^{1}$ Mohr, "Subjects and Objects."

${ }^{2}$ Bernard, "Penser autrement," 11.

${ }^{3}$ Oncini, "Feeding Distinction," 18-19; Bowen, Pressure Cooker; Franscesconi, Pratiche Alimentari.

${ }^{4}$ Caplan, "Approaches to the Study of Food"; Cohen, "Law and Political Economy."
}

This work is licensed under a Creative Commons Attribution 4.0 International Licence. As an open access journal, articles are free to use with proper attribution. ISSN: 2652-4074 (Online) 
From another viewpoint, food seems to be embedded in a normative or regulatory character, which makes authors use expressions, such as 'a corpus of culinary rules' or food as a code or relate food to obligations and, ultimately, to guilt, ${ }^{5}$ and virtually turns everyone into a judge, scrutinising ${ }^{6}$ others, and ourselves, for their (and our) food practices and choices. In the end, this leads everyone to responsibilise their (and our) relationship to food (in terms of good and bad food habits). In this regard, the drawing of boundaries between good and bad foods reveals the ways in which we engage in identity politics and cultural capital. ${ }^{7}$ Consequently, what we eat, where we buy, how we prepare (food techniques) and combine our food, and how we eat it, or who we eat it with, are bound up in a web of practices, commands and (formal, informal and religious) rules and rituals, defined by a variety of cultural practices, norms, values and habitus, and also by public policies and legislation. ${ }^{8}$

Despite such significance, food's relevance in legal scholarship has been quite secondary, ${ }^{9}$ apart from established questions in food law, like risk regulation, advertising, consumers' rights and food safety, trade laws and, more recently, the issue of food sovereignty ${ }^{10}$ (and food justice). ${ }^{11}$ Nonetheless, the complex intersections of food and law should be examined more often, for food, and what is attached to food, is an interdisciplinary tool offering epistemological apparatus to examine contemporary societal relations. ${ }^{12}$

In this regard, food appears to be scrambled with one specific area of law linked explicitly to societal relations: that of family law. However, such connection has not been habitually examined in previous sociolegal studies on families and food, and noticeably in legal scholarship. ${ }^{13}$ According to Asher and Cherry, ${ }^{14}$ food is a key tool in the creation and maintenance of 'the family'. Consequently, different foods, specific meals or dietary choices intertwine with familial relationships and are, therefore, directly and frequently related to family law, in a close dialogue between public and private spheres or between the kitchen and the courthouse.

For example, the Sunday lunch can be viewed as a metaphor with great symbolic power representing the family; its supposed decline ${ }^{15}$ may indicate changes in the nature of 'proper' family life, ${ }^{16}$ hence signalling possible intergenerational conflicts and/or the individualisation of family ties through the loss of sociality and conviviality over food. It seems compelling, and somehow reassuring, to think that if people make time for cooking food at home it will be possible to create stronger families. Even in the context of nutritional sciences this idea is clearly expressed. For example, Walton and colleagues claim that family dinners are associated with better dietary intake for adolescents from both high and low functioning families. ${ }^{17}$

However, this ideal of the Sunday lunch may obscure the fact that diverse families might use food differently in their familial sociality and, thus, create family in new ways. ${ }^{18}$ Italian anthropologist Marino Niola, ${ }^{19}$ for example, perceives the Sunday brunch (which he sees as being 'more than breakfast and less than lunch') as the new communal ritual that brings individuals together in a globalised and multicultural milieu. This mealtime becomes a site where the palette of flavours and foodstuffs is freer from previous gastronomic codes, presenting a simultaneity of (sweet and savoury) plates, which seems to reflect the individuals' choices of new familial typologies and a democratisation of family relationships, and where the (hierarchical and gender) divisions associated with traditional lunches (apparently) fade away. Thus, these alimentary changes may signal an evolution towards forms of contractualisation of familial relationships, which, no longer stipulated in the interest of the community and of the family as a nuclear unit but in the interest of the individual, require an ever-smaller interference from the law. Therefore, the Sunday brunch serves as a metaphor for flexible and more fluid familial arrangements (increased

\footnotetext{
${ }^{5}$ Kittler, Food and Culture; Johnston, Foodies; Cairns, "On (Not) Knowing."

${ }^{6}$ Francesconi, Pratiche Alimentari.

${ }^{7}$ Johnston, Foodies; Bourdieu, Distinction.

${ }^{8}$ Mohr, "Crossing Over"; van der Meulen, "The Structure of European Food Law."

${ }^{9}$ Bernard, "Penser autrement," 11.

${ }^{10}$ Freckelton, "Food Law"; Bellinger, "The Intersection," 45-48.

${ }^{11}$ Gonzalez, "Food Justice."

${ }^{12}$ Niola, Non tutto fa brodo; Sarat, "Editorial," 195.

${ }^{13}$ Bernard, "Penser autrement."

${ }^{14}$ Asher, "Home Is Where the Food Is," 77-79.

${ }^{15}$ Like Lindsay and Maher aptly argue, one cannot simplistically assume that changes to food or meal habits immediately signal a decline or a disintegration of family life. See Lindsay, Consuming Families.

${ }^{16}$ Caplan, "Approaches to the Study of Food"; Asher, "Home Is Where the Food Is," 77-79.

${ }^{17}$ Walton, "Exploring the Role of Family Functioning"; Bugge, "Domestic Dinner," 204.

${ }^{18}$ Lindsay, Consuming Families.

${ }^{19}$ Niola, "Elogio del brunch."
} 
numbers of de facto unions; higher rates of children born out of the wedlock; increased numbers of single-parent families, recomposed families and transnational families; and even the increase of single-person families), indicating the difficulty and, especially, the inadequacy of proposing a univocal definition of family. ${ }^{20}$

\section{From the Kitchen Table to the Judge's Bench}

When food comes into the realm of public concern and action, it is particularly prone to provoke legal conflicts. If, on the one hand, food aggregates, since similar patterns of food consumption can foster trust and cooperation ${ }^{21}$ among people, ${ }^{22}$ the opposite can also take place, for different patterns of food consumption can substantiate relational conflicts and disintegrate social bonds, transforming food into an instrument of division, intolerance and, ultimately, of exclusion. ${ }^{23}$ Therefore, when hegemonic food patterns and nutrition practices are resisted, or even rejected, and substituted by different ones, this situation is seen and felt as a social concern, ${ }^{24}$ because the order, or normalcy, provided to reality through (known and accepted) food gets twisted, with alarming effects. ${ }^{25}$

This seems to be particularly disturbing when children are involved. Preparing and serving food is considered a form of care, linked to ideas of love, and most often to maternal responsibility. ${ }^{26}$ Thus, food is a means through which adults express their care for children, but also their own feelings for each other.

Some questions, thus, arise: what if parents, and particularly mothers, challenge the (normalcy of the) omnivorous diet and decide, for health-related or ethical reasons, to choose an alternative dietary regime for their children (e.g., macrobiotic, vegetarian or even vegan)? What if both parents disagree on the matter, and take the conflict to the judicial system? ${ }^{27}$ What is at stake, then? Further, which values are embedded in the courts' judgements?

As Commaille ${ }^{28}$ claims, the law is a practice in constant exchange with the societies and cultures in which it develops, revealing the constant (and sometimes new-fangled) challenges societies and, therefore, the law come across. It is here food and alternative diets cross the threshold. In this framework, the choice of alternative food practices involving children, chosen or imposed by the parents (or just by one of them), has served as a bone of contention concerning, on the one hand, the regulation of parental responsibilities ${ }^{29}$ after divorce/separation, and, conversely, potential parental negligence ${ }^{30}$ as has happened in Italy in these last five years. These conflicts had to be resolved by the Italian courts - as in the cases of Bergamo, Cagliari, Monza and Rome (which I will discuss later, in particular the Roman case). Such conflicts over food and alternative diets do not only concern the singular cases; rather, they indicate we need to be aware of the disruptions and continuities that permeate familial structures, the normative-social regulation of such structures and the challenges that are posed to the courts in which food and associated conflicts serve as a very interesting focal lens. Hence, what begins with children's best diet(s) leads to the complexity

\footnotetext{
${ }^{20}$ Pedroso, "Mudam-se os Tempos". .

${ }^{21}$ And serve as a tool for social inclusion. On the issue of food as a symbolic and material resource that promotes the resilience and social inclusion of migrants, see Onorati, "Il cibo come risorsa."

${ }^{22}$ Wooley, "Recipe for Friendship," 1.

${ }^{23}$ Niola, "Siamo quello che non mangiamo."

${ }^{24}$ Maurer, Eating Agendas.

${ }^{25}$ Degnen, "Eating Genes," 50.

${ }^{26}$ Johnston, Foodies.

${ }^{27}$ A number of issues has to be resolved then, and it is ultimately up to the courts to decide, and in the Italian case in accordance to articles 337-bis and 337-ter of the Italian Civil Code.

${ }^{28}$ Commaille, À quoi nous sert le droit?, 11-12.

${ }^{29}$ To speak of parental responsibilities, whether in the constancy of marriage (or de facto union), after its rupture, or even when the union did not occur, means to speak of a set of powers and duties intended to guarantee the moral and material wellbeing of the child by ensuring education, livelihood, legal representation and the administration of property, which has been consecrated by the laws of many countries. However, it is not only the parents who must do it, there are several actors with responsibilities towards children: many constitutions state it is up to society and the State to protect children, and their integral development, which implies a series of guarantees, such as the right to health. In this framework, articles 24 and 27 of the Convention on the Rights of the Child, adopted in 1989, state it is the responsibility of Parties States to combat child malnutrition, and to ensure parents, or other persons responsible for the child, provide material assistance and food nutrition.

30 This led an MP, Elvira Savino (from Forza Italia), to propose a law (Atto Camera 3972, in 2016) to change the Penal Code to sentence to prison parents who give a vegan diet to their children (under the age of 16). Compare

https://www.google.com/search?q=elvira+savino+veganismo+legge\&ei=rXbOXeuNGJDTsAflx4boDg\&start=10\&sa=N\&ved=0ahUKEwir mP2S-uvlAhWQKewKHeWjAe0Q8NMDCMIB\&biw=1280\&bih=881 (last accessed 15 November, 2019). This was later dropped out.
} 
underpinning the ideals of childhood (protecting the child's innocence and health) and parenthood (the parents' rights and duties involved in parenting), and how these interlink with notions of the family, gender expectations and biopolitics.

\section{The Italian Court Decisions}

In the last five years, the Italian civil ${ }^{31}$ courts have ruled on attention-grabbing cases regarding the recognition of a right to feed alternative diets to children, in cases concerning both parental responsibilities and the best interests of the child, sometimes with contrasting decisions. ${ }^{32}$ Although the courts have dealt with cases involving diets and the bests interests of the child before, especially in what regards the parents' religious choices, ${ }^{33}$ what is interesting about the recent cases has not only to do with the contrasting character of the decisions, but with what they may reveal. Like Francesconi and Raiteri claim, ${ }^{34}$ some of these decisions - and particularly the Roman one ${ }^{35}$ — seem to reveal a deviant or non-conforming stance to the norms regarding those parents who choose to give an alternative diet to their children. I will develop this argument in section 'Normality I' by drawing on Canguilhem's categories of the normal and the pathological.

The cases: ${ }^{36}$

- In 2015, the court of Bergamo, after the father contested the unilateral maternal decision of feeding the child a macrobiotic diet, ${ }^{37}$ ruled the child should eat meat at least once a week when residing with the mother, and no more than two times during the weekends spent with the father (Sentenza n. 28, 2015).

- In Monza, in 2016, after the mother's appeal concerning an earlier decision (the Children's Court of Milan, given the parent's disagreement, had ruled the child should follow an omnivorous diet instead of the vegan one, which the Court considered inadequate), the court of Monza ruled that the 8-year-old child could follow the vegan diet, since there were no health problems derived from such food practices (Decreto 5 luglio 2016, n. 10984). Nevertheless, the Court also imposed there should be periodical medical examinations to ensure the child's health was not under stress.

- In 2017, the Children's Court of Cagliari (Tribunale dei Minorenni) decided, similar to the Monza judgement, that there is no violation of parental responsibilities on the part of parents choosing a vegan diet for their minor child, as long as it is followed correctly and in accordance to medical expert advice so as not to hinder the regular growth of the child (Decreto 09/06/2017).

Nevertheless, the most interesting decision, from my point of view, is that from the Civil Court of Rome. In a judgement dated 19 October 2016, following the request of the father to modify the regulation of the exercise of parental responsibilitieswhich, in addition to the visiting scheme, required that the child should adopt an omnivorous diet instead of the vegan diet she was consuming; moreover, a diet that had been decided unilaterally by the mother without the consent of the father (and which the mother had requested should also be adopted at the school canteen) — the Roman Court established the need for the child to follow a varied and 'unrestricted' diet, one that would assure healthy growth and development. To enact its judgement, the Court made explicit reference to the following criteria: (1) the best interests of the child (related specifically to the child's healthiness - even if the Court attested that the child's well-being was not under any stress), (2) the parameters of statistical normality (infant growth charts), (3) the normal parental conducts in the generality of the cases and (4) the regular food menus served by public school's canteens.

What, then, becomes salient in the Roman pronouncement?

\footnotetext{
${ }^{31}$ Likewise, the administrative courts (like Torino, Bolzano and Naples Administrative Courts) have had to decide conflicts regarding dietary issues. I will come back to this issue later.

${ }^{32}$ Musio, "Scelte alimentari."

${ }^{33}$ Fucillo, Diritto, Religione, Culture, 518.

${ }^{34}$ Francesconi, Pratiche Alimentari.

35 The particularity of the Roman case is deeply connected to the extended case method, which consists of the dense analysis of cases, in this context of judicial cases, that are qualitatively representative for their exemplarity and uncommonness; thus, revealing the social, political and cultural conditions and contradictions of their contexts. See Santos, As bifurcações da ordem, 14.

${ }^{36}$ A brief methodological note regarding the cases is needed. As I said in the previous footnote, I make use of the extended case method when analysing the Roman decision not only because of its particularity, but also because it is the longest and the more argumentative one. All the other decisions are quite brief (less than a page). Moreover, not all of them were in open access format (like in the cases of Bergamo and Monza) and, thus, secondary sources were the only relevant way to access such court decisions.

${ }^{37}$ Compare http://www.ansa.it/lombardia/notizie/2015/05/28/lei-macrobiotica-lui-carnivoro-in-tribunale-per-figlio_1634c50f-02e5-4cbcb225-8c66f124e98b.html (last accessed 15 November, 2019).
} 


\section{'Oh, Sweet Child of Mine'}

As we know, ideals of parenthood and childhood are not fixed structures, but reflect wider social and cultural concerns that have changed during the course of time. ${ }^{38}$ Further, the child, especially in Western societies, has been filled with innocence and purity, and is seen as the promise of the future. Consequently, investments in children assume a heightened meaning within the contemporary context of economic, political, social and environmental insecurity. ${ }^{39}$ Thus, children are seen as needing special protections, and this has become particularly salient in the domain of feeding practices and dietary regimes, since the parents do not only feel, but are held to be, responsible for rearing a healthy child while also preserving the planet. Even the United Nations International Children's Emergency Fund report ${ }^{40}$ is clear on this when stating the goal to achieve is to provide children with diets that are nutritious, safe, affordable and sustainable.

To a greater extent, there seems to be a confluence between intensive parenting (usually connoted with mothering) — children must be carefully cared for through extensive and intensive investments of time and resources for which parents must provide, and through intensive feeding - by choosing, shopping and cooking the best foodstuffs, and encouraging ethical and healthy practices children can uphold and carry on in the future. ${ }^{41}$

Even if, in recent times, infancy and youth have gained prominence and a different social and legal status, children's lives are still lived according to the models and definition of infancy the adults have constructed for them..$^{42}$ As I wrote before, food is one of the ways adults express their love and care for children. Nevertheless, this type of care also encompasses forms of adult control over children's food consumption and practices ${ }^{43}$ that surpass the parents' responsibility and involve a whole range of significant institutions concerning children and childcare. Under nutritional and medical sciences, families, and children in particular, have become a matter of both public scrutiny, on the one hand, and, conversely, of private responsibility, as parentsmost frequently mothers - are expected to purchase and cook the appropriate (healthy) food products for their children. ${ }^{44}$ This commitment to healthier family food practices has become more evident since childhood obesity has been identified as one of the critical public health problems of the present. ${ }^{45}$

In this context, there is an increase in state intervention aimed at regulating the social consequences of familial choices and practices, particularly regarding the relationship between parents and children, in the name of the best interests of the child. The best interests of the child also contain in itself an idea of future, since protecting the children means protecting the survival of the family, community and even humankind. ${ }^{46}$ Hence, and in all actions concerning children, the best interests of the child are of primary consideration.

\section{The Best Interests of the Child, and Parents' Dietary Choices}

The notion of the best interests of the child, ${ }^{47}$ well known in family law, and particularly concerning parental responsibilities, is part of that typology of indeterminate legal concepts that contains in itself a plurality of meanings (legal and other), and places the child at the centre of the decision-making process on a case-by-case basis. ${ }^{48}$ However, by being indeterminate, the best interests of the child allow a variety of interpretations. Regardless of its undetermined nature, it has a tremendous effect on the life of the families. ${ }^{49}$ Further, like Lamarque recalls, ${ }^{50}$ the best interests of the child is an effective argument because its invocation is enough to silence any other claim.

\footnotetext{
${ }^{38}$ King, "Concepts of Childhood"; Casaleiro, Justiça procura Perícia(s).

${ }^{39}$ Cairns, "Feeding the 'Organic Child," 97-98.

${ }^{40}$ United Nations International Children's Emergency Fund, Children, Food and Nutrition.

${ }^{41}$ Cairns, "On (Not) Knowing."

${ }^{42}$ Sani, "Reflexões sobre infância."

${ }^{43}$ Punch, "Children's Food Practices," 227-232.

${ }^{44}$ Oncini, "Feeding Distinction," 18-19.

${ }^{45}$ Lindsay, Consuming Families.

${ }^{46}$ Hammarberg, "Principle of the Best Interests of the Child."

${ }^{47}$ Compare the Convention on the Rights of the Child, the European Convention on the Exercise of Children's Rights and articles 29 and 30 of the Italian Constitution.

${ }^{48}$ Skivenes, "Child's Best Interest Principle," 59-61.

${ }^{49}$ Simões, "Representações"; Andreola, "Dieta vegana per il figlio," 575.

${ }^{50}$ Lamarque, Prima i bambini.
} 
According to Sicchiero, ${ }^{51}$ the best interests of the child can be divided into three main aspects: (1) what the child considers to be his/her interests, (2) what the parents consider to be the child's interests and (3) what a third party (above all health authorities, social services and the courts) considers to be the child's best interests. This decision-maker must then consider a range of issues, like education, attachment and, of course, nutrition. ${ }^{52}$ Hence, and in any case, the decision-maker will have to decide (1) when there is a pathologic behaviour by the parent(s) that endangers the child, or (2) when there is a conflict between the parents as to the decisions to be taken regarding the child. ${ }^{53}$ Thus, the principle of the best interests of the child serves as a judgement criterion and a parameter of assessment. ${ }^{54}$

Moreover, and even if the parents do have the right to educate their children in accordance with their own pedagogical and ethical-moral convictions, this power duty must be exercised within the limits of the child's interests, and also in accordance with the will of the child, whose voice must be listened to. ${ }^{55}$

Consequently, this has led to constant monitoring of the children's development, and to unprecedented surveillance of children and familial practices, as Mayall claims. ${ }^{56}$ The protection of childhood, thus, seems to entail, in many cases, a repressive, disciplinary-like character, with authorities seeking to shape familial choices and practices. ${ }^{57}$

Accordingly, and the Italian decisions described earlier make it clear, the prime concern in terms of the best interests of the child when it comes to family food practices ${ }^{58}$ appears to be the child's health. However, there seems to be a tendency to fixate on issues of (mal)nutrition, particularly regarding poor growth and development, ${ }^{59}$ when it comes to the families' food choices concerning children. ${ }^{60}$ This was clear in all the Italian cases. Further, we have to be aware that in many of the cases in which children were fed under a dietary regime deprived of certain foodstuffs (often without any medical backing), children were severely malnourished ${ }^{61}$ (and some even died). ${ }^{62}$

\section{Children, Mums and Dads: Feeding the Family}

Where children are present, there seems to be a very strong societal prescription according to whether a child's well-being is the mothers' responsibility, particularly in terms of feeding provision. ${ }^{63}$ Hence, mothers get trapped in a web of regulation and normalisation, in which the paradigm is that of the ideal mother-one who instils in her children appropriate eating habits and, thereby, protects them from malnutrition. ${ }^{64}$ The mother who does not follow this ideal is considered suspicious, even 'unloving'.

\footnotetext{
51 Sicchiero, "La nozione," 74-75.

52 Skivenes, "Child's Best Interest Principle," 59-61.

53 Sicchiero, "La nozione," 74-75.

${ }^{54}$ Fucillo, Diritto, Religione, Culture, 518.

55 Andreola, "Dieta vegana per il figlio," 575.

56 Mayall, "Sociology of Childhood."

${ }^{57}$ Donzelot, Policing of Families; Casaleiro, Justiça procura Perícia(s).

${ }^{58}$ One good example stressing the tensions between dietary choices, parenting and the best interest of the child is offered by Zivkovic and colleagues, who analysed judicial cases concerning childhood obesity in Australia. One of the results of their study was that it was only recently that childhood obesity began to be viewed as a question of parental neglect, meaning the families were compelled to change their habits in regards to food choices. Further, Zivkovic and colleagues concluded that the responsibility for feeding children falls especially upon the mothers. Their case study found that mothers were the ones being held culpable in cases of neglect concerning child obesity. Zivkovic, "In the Name of the Child."

${ }^{59}$ In Portugal, for example, there have been some cases of privational rickets that were specifically linked by the medical doctors to the adoption of vegan diets. Thus, Moutinho and colleagues argue that it may be necessary, in some situations of malnutrition related to a vegan diet, to judicially prosecute the families for childhood abuse and parental negligence. Moutinho, "Raquitismo Carencial," 58.

60 Graham, "Dual-Heritage Households," 4.

61 These situations are different from the situations of children affected by severe acute malnutrition from the poorest and most marginalised communities, as reported by the UN. Compare The State of the World's Children 2019 report.

62 In 2017, a Belgium Court convicted two parents for the death of their son on the causes of malnutrition provoked by an 'unconventional' diet. Compare https://www.independent.co.uk/news/world/europe/baby-dies-diet-parents-convicted-lucas-dendermonde-belgiummalnutrition-dehydration-a7790916.html (last accessed 15 November, 2019). Recently, a couple from Florida, US, has been criminally charged after their youngest son died of malnutrition. Compare https://www.phillyvoice.com/vegan-parents-charged-malnourished-soncape-corals-florida-investigation/ (last accessed 22 November, 2019).

${ }^{63}$ DeVault, Feeding the Family.

${ }^{64}$ Zivkovic, "In the Name of the Child."
} 
Accordingly, in the framework of childhood obesity preoccupations, ideals of maternal responsibility for health and care have increased yet again. ${ }^{65}$

For example, having examined the United Kingdom's context, Brown, ${ }^{66}$ argues that the legal understanding of 'family' continues, despite the many legal reforms that took place in the last decades, to be underpinned by the ideal of the 'nuclear family', premised upon the traditional, gendered roles of 'father as breadwinner' and 'mother as homemaker' and, thus, underestimating, or perhaps even naturalising, women's roles regarding foodwork and parenting. Even in societies where gender equality is the official policy, like in Norway, the majority of foodwork continues to be done by women. ${ }^{67}$ Gendered responsibility for families' food choices is also attested by men's unhealthy food behaviours after divorce, separation or widowing. ${ }^{68}$ These examples convey a traditional understanding: the wife/mother as the primary caregiver, in compliance with the rules, (first) sociocultural and (then) juridical.

Even if fathers are becoming more participative in family life, as Wall and colleagues ${ }^{69}$ have concluded, they are still viewed as the main provider of the family, whereas mothers continue to be seen as the primary caregivers, not only of young children, but of the whole family. This was rather obvious in the Italian court cases under analysis.

In the Italian court cases, the conflict between the parents had to do, in most situations, with an individual choice, usually imposed by the mother, without the father's consent. On the one hand, the mothers claimed the importance of a healthier dietary regime (which echoes Beagan and colleagues' argument). ${ }^{70}$ For example, in the Roman case, the mother argued her choice was based on 'the alleged lower wholesomeness of foodstuffs of animal origin of undetected sources, as well as the presence of harmful ingredients in packaged foods'. It looks as if mothers feel personally accountable for protecting children's health and purity in the context of an industrialised and market-based food system. Hence, the idea of convenience food ${ }^{71}$ is marked with moral disapproval, as it seems to conflict with ideals of care. ${ }^{72}$ Moreover, the fact that it is the mothers who feel responsible for feeding the family is, thus, closely linked to dominant gendered constructions of femininity, maternal responsibility and health. ${ }^{73}$ Conversely, and as pointed out by Johnston and Baumann, ${ }^{74}$ there is a moral censure of those mothers who do not cook, and who buy frozen meals or order takeout as opposed to the morally irreprehensible ideal of the 'nurturing mother', who prepares meals for the whole family.

Second, there seems to be a change in terms of the fathers' involvement in the child's life in a more positive and proactive manner. In this regard, a number of studies point out that food provision is increasingly becoming a crucial part of their fathering. ${ }^{75} \mathrm{Holm}$ and colleagues ${ }^{76}$ have shown that in Nordic households, men's participation in the cooking of dinner has increased significantly. Nevertheless, women still cook more frequently than men. In contrast, men who want to do their share of the foodwork also have to deal with hegemonic patterns of masculinity.

Regarding the Italian cases, what becomes salient in the fathers' conduct is that they too express a concern for the child's health in terms of malnutrition by equating a vegan diet with a health menace and an unrestricted diet, especially one in which meat consumption is a key element, with good nutrition and a healthy regime.

\footnotetext{
${ }^{65}$ Wright, "Social Class," 424-425.

${ }^{66}$ Brown, What is the Family of Law?

${ }^{67}$ Bugge, "Domestic Dinner," 204.

${ }^{68}$ Vinther, "Marital Transitions," 120.

${ }^{69}$ Wall, A vida familiar no masculino.

70 Beagan, “It's Just Easier."”

71 This poses a number of questions. How are disadvantaged families examined and evaluated by social and health services, and later by the courts? What problems are identified through their food practices? And what values are propelled under the 'ideal' of adequate food? This leads to further questioning: how are families, and particularly mothers with limited economic and cultural capital, seen and judged? Moreover, are we not de-responsibilising other actors in the matter, since prevailing media and political discourses tend to obscure economic constraints and blame parents for poor diets and for not inculcating appropriate attitudes to food and exercise? There is a complexity of questions around (alternative) diets and/or economically disadvantaged families - who both seem to be trapped in a web of regulation and normalisation - that needs a systemic way of reflecting upon them.

72 Cairns, "Feeding the 'Organic Child."”

${ }^{73}$ Cairns, "On (Not) Knowing."

${ }^{74}$ Johnston, Foodies.

${ }^{75}$ Neuman, "Feeding the Extended Family," 45-47.

${ }^{76}$ Holm, "Cooking and Gender," 135.
} 


\section{'Flesh of My Flesh' v. 'Quinoa of My Quinoa'}

An emerging theme in the literature is that food consumption is gendered, suggesting that meat is an exemplary masculine food whereas women will often prefer a vegetarian-type diet. ${ }^{77}$ For example, data from the US confirm that women eat about onethird less meat than men overall. ${ }^{78}$ Further, in most affluent countries, annual meat consumption shows high intakes in excess of $100 \mathrm{~kg} / \mathrm{capita} .{ }^{79}$ As a result, the EAT-Lancet commission's report calls for major reductions in red meat eating, primarily by reducing excessive consumption in wealthier countries. ${ }^{80}$

This has probably led other authors to suggest an equation between meat eating and hegemonic masculinity; ${ }^{81}$ as such, the consumption of meat would mean subscribing to and reinforcing the norms, expectations and behaviours of either gender in a patriarchal culture. ${ }^{82}$ Bourdieu's analysis of the French context in the 1980s has also shown that meat is observed as 'the dish for men' - as the 'nourishing food par excellence' — and, hence, as a superior food, which is based on an energetic conception of food in which meat is more valued. ${ }^{83}$ The act of eating meat seems to remain compliant to social logics of distinction, often cloaked in health and dietary assessment criteria. ${ }^{84}$ Thus, the link between meat consumption and good health is still quite powerful, ${ }^{85}$ as attested by the fathers' claims in the Italian context.

As well, the idea of flesh evokes familial relations, particularly those between parents and children. According to Sobal, meat is often a contested food in marriage, ${ }^{86}$ and, as the Italian cases confirm, such contestation even escalates when the marriage is over. This time, the contestation is over the children's meat or meat-free consumption.

Thus, choosing to consume a meat-free diet seems to transgress dominant cultural and gastronomic norms and the values invested in such norms. ${ }^{87}$ In addition, it seems as if the debate over meat between the parents is, once more, ratifying (1) the traditional 'family values' schema in which alternative forms of parenting become deviant through food, and (2) that mothers are responsible for the children's health, and those mothers preferring quinoa over meat are probably judged as more responsible than those mothers who give meat to their children, even when children are growing healthily (although within an inferior percentile, a situation that can occur regardless of adhering to a vegetarian/vegan diet).

\section{Normality I}

The concern for the child's health in terms of malnutrition involves other figures, apart from mother and father. Thus, we have the health authorities, social services and the courts. The court's reliance on those experts' records shows how dependent the law is on other knowledges, particularly on scientific/medical knowledge ${ }^{88}$ Here, the conflicts are multiple, as each parent will have their own doctor's record, the court will have its own and these more often than not diverge.

The discourse behind the Roman Court's decision is based, primarily, on the ideals of statistic normality, once food allergies or intolerances were discarded. The Court started by declaring that the health certificates do attest the child's good health. Nonetheless, the father's certificate showed, according to the Court's reasoning, that the child's growth was in the 15th percentile, placing her in an inferior size compared with other girls of the same age. Therefore, the Court decided that, to respect statistic normality, the child should adopt a diet without any type of food restriction, since this was regarded by the Court as the only way capable of guaranteeing the child's well-being.

\footnotetext{
${ }^{77}$ Sobal, "Men, Meat, And Marriage”; Nath, "Gendered Fare?," 262-263.

${ }^{78}$ Compare http://www.countinganimals.com/meat-consumption-patterns-by-race-and-gender/ (last accessed 22 November, 2019).

79 Smil, "Worldwide Transformation of Diets," 207.

${ }^{80}$ Compare https://eatforum.org/eat-lancet-commission/ (last accessed 22 November, 2019).

${ }^{81}$ Greenebaum and Dexter argue that vegan men align with traditional masculine standards by modifying values associated with veganism, by using aggressive language, accentuating physical fitness and emphasising heterosexuality. Greenebaum, "Vegan Men."

${ }^{82}$ Blue, Consuming Flesh.

${ }^{83}$ Bourdieu, Distinction; Labarre, "Les trois dimensions."

${ }^{84}$ Frauenfelder, "Consommations de viande," 60-62.

${ }^{85}$ Greenebaum, "Vegan Men."

${ }^{86}$ Sobal, "Men, Meat, And Marriage."

${ }^{87}$ Nath, "Gendered Fare?." 262--263.

${ }^{88}$ Casaleiro, Justiça procura Perícia(s).
} 
Interestingly, though, the Court does not provide us with a definition of what it means by statistic normality. Normality usually means conforming to a type, standard or regular pattern. ${ }^{89}$ Does it mean that by being at the 15 th percentile, the child was not growing up normally? The Court does not refer, in any point of the decision, if the child's growth over time was in another percentile (deviation) or if the 15th percentile had been the child's pattern of growth, which would show a regularity or normality. The Court does refer to the child's good health and, hence, the absence of pathologies. This clearly illustrates Canguilhem's argument ${ }^{90}$ that qualitative and holistic notions of well-being and health were outpaced by quantitative and technical apparatus. ${ }^{91}$

As Canguilhem has shown, ${ }^{92}$ categories of the normal and pathological are far from being objective scientific concepts, and are embedded in political, economic and technological imperatives. ${ }^{93}$ Underneath the concept of normality, there is a claim to normativity. Thus, the process of normalisation that intends to concretise this normativity project implies the sanction (and sometimes the elimination) of the anomalies. These corrective techniques operate vis-à-vis disciplinary technologies. ${ }^{94}$

Thus, these disciplinary technologies, or technologies of normalisation, have a scientific aura. Growth charts/percentiles could be seen as such, even when these percentiles are being changed ${ }^{95}$ all the time to adapt to new realities. What the Roman Court's decision displays is that institutions play a role in constructing the discursive conditions for health, under the cape of the best interests of the child. This is in line with Foucault's concept of biopolitics, ${ }^{96}$ according to which the state's institutions heavily rely on statistics, ${ }^{97}$ creating disciplinary regimes aimed at regulating society: percentiles, diets and discipline. And ethics.

\section{The Microtechnology of Ethical Eating}

As I wrote before, to account for the child's health condition, the Roman Court had to refer to the medical records arranged by each parent, and these diverged. This divergence is said to be anchored in prejudice, the Italian lawyer Carlo Prisco argues. ${ }^{98}$ A self-proclaimed vegan, this lawyer has become an expert in vegan-related judicial matters, and is often the legal representative of many parents in court cases, as in the Roman one (in which he represented the mother). Prisco claims the courts avail their ruling on pseudoscientific preconceptions, as medical doctors are wrongly persuaded of the fact that children's health is endangered by a vegan diet. This might be a strong argument, as the (Bergamese and) Roman decision illustrates. However, Prisco appears to fall into this very trap of the pseudoscientific preconception when claiming the omnivorous diet is the one to be challenged as the more dangerous (or pathological) diet, apparently based solely on his knowledge and expertise as an averagely informed vegan. ${ }^{99}$ This clearly illustrates Hacking's argument: ${ }^{100}$ that individuals become the objects of knowledge themselves.

Moreover, Prisco defines the omnivorous diet as nutritionally poor-based on snacks, refined sugars, red meat and low intake of fruits and vegetables. This is, somehow, a bizarre definition, and seems to shadow two types of stereotypes: (1) that of the uneducated poor person making unhealthy food choices and (2) that of the unconscientious parent, who will not feed their child nutritious and ethically superior foods. Thus, he arrogates to himself the privilege of (scientific and truthful) knowledge,

\footnotetext{
${ }^{89}$ Compare https://www.merriam-webster.com/dictionary/normal (last accessed 26 November, 2019).

${ }^{90}$ Canguilhem, Normal and the Pathological.

${ }^{91}$ Gotkin, "Norm and the Pathological."

${ }^{92}$ Canguilhem, Normal and the Pathological.

${ }^{93}$ In this context, it is worth mentioning Bentley's study regarding the influence of the market, and advertising, on the notion of infant feeding in the beginning of the twentieth century, from which the medicalisation of motherhood and a constant questioning of parenting skills gave rise to a discourse on the inadequacy of breast milk, which should be replaced first by artificial milk, and then by canned homogenates, introduced at earlier ages, simultaneously creating a variety of products and inducing their consumption for as long as possible. To this end, and by emphasising the scientific discourse behind the products (the nutritional values and the cooking process), advertising was based on a mix of discourses, affecting family relationships (of affiliation and marriage): less time in the kitchen meant more time for mothers to devote themselves to offspring and husbands, implying a clear division of household chores and accentuating the roles of mother and wife. Bentley, "Feeding Baby, Teaching Mother."

${ }^{94}$ Campesi, "Norma, Normatività, Normalizzazione."

${ }^{95}$ Dibley, "Development of Normalized Curves."

${ }^{96}$ Burchell, Foucault Effect.

${ }^{97}$ Muller, "Governmentality and Biopolitics."

${ }^{98}$ Compare http://it.vegephobia.info/index.php?post/2015/05/14/L\%E2\%80\%99ultima-inquisizione-\%28togliere-i-figli-ai-genitorivegetariani\%29-di-Carlo-Prisco (last accessed 26 November, 2019).

${ }^{99}$ Compare https://genitoriveg.com/scelte-vegane-vegetariane-separazione (last accessed 26 November, 2019).

${ }^{100}$ Hacking, Historical Ontology.
} 
determines the normativity of the vegan diet as ethically superior and delegitimising other food practices and enacts a moral judgement and disapprobation against those who do not see it like him.

However, there is more to Prisco's considerations, which are also entwined to the mother's argumentation in the Roman case. Individuals become responsible for themselves by mastering and controlling their diets and food practices, ${ }^{101}$ by which individuals control their bodies. Dietary regimes can be seen to constitute apparatuses to discipline the bodies, or what Foucault ${ }^{102}$ termed the political technology of the body. Governmentality presumes the existence of disciplinary regimes aimed at regulating society, but it also works based on the microtechnologies of power by which individuals govern themselves: ${ }^{103}$ daily ethical practices performed upon the self, such as ethical eating practices.

In this particular context and inferring from Prisco's stance, Prisco's arguments show there is an interlocking system of microtechnologies of power that are associated with food choices, food preparation and cooking (mainly at home), and that govern and exert pressure on individuals. In this system, diets serve as codes of conduct establishing margins of inclusion and exclusion.

\section{Normality II}

The idea of the averaged informed subject is also quite present in the decision of the Roman court when ruling by reference to the 'conducts normally held by the parents in the generality of cases', and according to this court, to the provision of a dietary regime without any food restriction. Further, it invoked the menus served at the (public) school cafeterias, declaring the schools' menus serve a correct diet without posing any health risks, because these menus are delineated by the health and school ministries and are under public scrutiny.

The argument regarding the conducts normally held by the parents in the generality of cases is quite vague, and again refers to ideas of normality and standardisation of behaviours. In what concerns children and diets, this is even more puzzling, since the daily interaction at the family table is quite different from that fallacious depiction of the "dominant hegemonic nutritious meal of parental harmony and social integration' we always hear about. ${ }^{104}$

Second, invoking schools' menus utterly disregards the several conflicts and court cases in which school menus have been under attack. As I wrote before, the Italian administrative courts have had to decide conflicts regarding dietary issues as well. ${ }^{105}$ Such cases dealt with parents opposing school boards over the existence of a right to consume a meal other than that provided through the meal service within public school facilities (and usually brought from home), particularly given the parents' dissatisfaction with the quality of the meal served in relation to its cost. One of the most recent decisions on the so-called 'right to the panino' has been enacted by the Italian Supreme Court of Cassation, in July 2019 (Sentenza no. 20504/19), ruling that the sandwich brought from home to replace the food provided in the school canteen cannot be allowed in the canteen and school premises. Curiously, though, an even more recent decision, enacted by Lazio's Regional Administrative Court (Sentenza no. 14368/19), goes against the Cassation's one, establishing that, if they want to, parents are free to send food prepared at home to be eaten by their children at school. Thus, the decision ascertains the right of the families to decide on how to feed their children.

Both decisions are quite interesting, and reveal how the courts express the limits and dissenting views of the law. Further, the Lazio Regional Administrative Court's decision seems to contest the ideas of standardisation of behaviours expressed by the Roman decision. Actually, families have many different food practices, dictated by the complexity of family engagements with food, shaped by many factors, such as culture, geography, the economic resources of each family and religion. Moreover, because each child is different and expresses individual tastes and food choices, each family has to adapt their practices to maintain family harmony. This may imply diets that are quite restricted. Moreover, the idea of the average parent as feeding the child an 'unrestricted diet' seems to reveal, again, the embedded assumption and cultural legitimacy of meat consumption as healthier for children.

\footnotetext{
${ }^{101}$ Labarre, "Les trois dimensions."

102 Foucault, Surveiller et Punir, 34.

${ }^{103}$ Binkley, "Work of Neoliberal Governmentality," 62.

${ }^{104}$ Ehn, Exploring Everyday Life.

${ }^{105}$ Boggero, "“There is no such thing as a free lunch."”
} 


\section{Concluding Remarks}

Food and diets press the courts into deciding on important matters. The Italian decisions show us that, but they show us more. These decisions call attention to ongoing debates about children and parenting, particularly to the links between the cultural normativities behind food practices, the ideals of family and childhood care and gender inequalities.

However, in all the discussions, one voice is rarely heard: that of the child. What about their food choices and preferences? Their alimentary agency? Just like Hammarberg ${ }^{106}$ has pointed out, the court decisions I have examined clearly illustrate that best interests' actions are sometimes based on condescending behaviours by the adults, who tend to discuss what is best for children without seeking their opinions or even listening to them. There is no indication from the decisions that the children involved in such court's cases were ever listened to.

Thus, what emerges is the judges' concern in finding a balance between the opposing claims of the parents, rather than assessing what, in the concrete case, were the actual interests of the minors involved. ${ }^{107}$ Moreover, there seems to be an imposition to normalise practices and behaviours; children and parents are to be educated towards food practices that are viewed as according to the norm (normal), and avoid those considered as deviant (pathological). Drawing on Canguilhem, it looks as if percentiles have turned into technologies of normalisation, especially when children are involved. Cloaked in arguments of health, nutrition and, particularly, by invoking the best interests of the child, these apparatuses expand on old power relations between adults and children, between mothers and fathers and between carnivores and vegetarians.

Thus, it seems as if alternative dietary regimes and food practices turn into macrotechnologies of power. This, unquestionably, establishes symbolic boundaries related to social, economic and cultural capital, and underestimates the complex associations of gender, class, economic constraint and geographical context, and how these shape the choices of what to eat and what to feed children.

\footnotetext{
${ }^{106}$ Hammarberg, "Principle of the Best Interests of the Child."

${ }^{107}$ Musio, "Scelte alimentari," 11.
} 


\section{Bibliography}

Andreola, Emanuela. "Dieta vegana per il figlio tra interesse del minore e responsabilità genitoriale". Famiglia e diritto. Mensile di legislazione, dottrina e giurisprudenza, no 6 (2017): 574-578.

Asher, Kathryn and Elizabeth Cherry. "Home Is Where the Food Is: Barriers to Vegetarianism and Veganism in the Domestic Sphere". Journal for Critical Animal Studies 13, no 1 (2015): 66-91.

Beagan, Brenda, Gwen E. Chapman, Andrea D’Sylva and B. Raewyn Bassett. “'It's Just Easier for Me to Do It': Rationalizing the Family Division of Foodwork". Sociology 42 (2008): 653-671. https://doi.org/10.1177\%2F0038038508091621

Bellinger, Nathan and Michael Fakhri. "The Intersection Between Food Sovereignty and Law”. Natural Resources \& Environment 28, no 2 (2013): 45-48.

Bentley, Amy. "Feeding Baby, Teaching Mother: Gerber and the Evolution of Infant Food and Feeding Practices in the United States". In From Betty Crocker to Feminist Food Studies: Critical Perspectives on Women and Food, edited by Barbara Haber and Arlene Voski Avakian, 62-88. Massachusetts: University of Massachusetts Press, 2005.

Bernard, Alain, François Collart Dutilleul and Fabrice Riem. "Penser autrement le rapport du droit et de l'alimentation. Présentation du dossier". Droit et Société 101 (2019): 11-20.

Binkley, Sam. "The Work of Neoliberal Governmentality: Temporality and Ethical Substance in the Tale of Two Dads". Foucault Studies, no 6 (2009): 60-78. https://doi.org/10.22439/fs.v0i0.2472

Blue, Gwendolyn G. "Consuming Flesh: The Biopolitics Of Beef Consumption”. PhD diss., University of North Carolina, 2006.

Boggero, Giovanni. “"There is no such thing as a free lunch'. Il pasto domestico a scuola come diritto costituzionalmente garantito?" In Alimentare i diritti culturali, edited by Jörg Luther and Giovanni Boggero, 99-134. Canterano: Aracne Editrice, 2018.

Bourdieu, Pierre. Distinction: A Social Critique of the Judgment of Taste. Harvard: Harvard University Press, 1984.

Bowen, Sarah, Joslyn Brenton and Sinikka Elliott. Pressure Cooker. Why Home Cooking Won't Solve Our Problems and What We Can Do about It. Oxford: Oxford University Press, 2019.

Brown, Alan. What is The Family of Law? The Influence of the Nuclear Family. Oxford: Hart Publishing, 2019.

Bugge, Annechen Bahr and Reidar Almas. "Domestic Dinner. Representations and Practices of a Proper Meal among Young Suburban Mothers". Journal of Consumer Culture 6, no 2 (2006): 203-228. https://doi.org/10.1177\%2F1469540506064744

Burchell, Graham, Colin Gordon, and Peter Miller (eds.). The Foucault Effect: Studies in Governmentality. Chicago: University of Chicago Press, 1991.

Cairns, Kate, Josée Johnston and Norah MacKendrick. "Feeding the 'Organic Child': Mothering through Ethical Consumption". Journal of Consumer Culture 13, no. 2 (2013): 97-118. https://doi.org/10.1177\%2F1469540513480162

Cairns, Kate and Josée Johnston. "On (Not) Knowing Where Your Food Comes From: Meat, Mothering and Ethical Eating”. Agriculture and Human Values, 35 (2018): 69-580. https://doi.org/10.1007/s10460-018-9849-5

Canguilhem, Georges. The Normal and the Pathological. New York: Zone Books, 1991.

Campesi, Giuseppe. "Norma, normatività, normalizzazione. Un itinerario teorico tra Canguilhem e Foucault". Sociologia del Diritto 2 (2008): 5-30.

Caplan, Pat. "Approaches to the Study of Food, Health and Identity". In Food, Health and Identity, edited by Pat Caplan, 130. New York: Routledge, 1996.

Casaleiro, Paula. "Justiça procura Perícia(s). Os processos de regulação das responsabilidades parentais”. PhD diss., Universidade de Coimbra, 2017.

Cohen, Amy. "The Law and Political Economy of Contemporary Food: Some Reflections on the Local and the Small". Law and Contemporary Problems, 78 (2015): 101-145.

Commaille, Jacques. À quoi nous sert le droit?. Paris: Gallimard, 2015.

Degnen, Cathrine. "Eating Genes and Raising People: Kinship Thinking and Genetically Modified Food in the North of England". In European Kinship in the Age of Biotechnology, edited by Jeanette Edwards and Carles Salazar, 45-63. New York/Oxford: Berghahn, 2009.

DeVault, Marjorie. Feeding the Family. The Social Organization of Caring as Gendered Work. Chicago: University of Chicago Press, 1991.

Dibley, Michael J., Jackie Goldsby, N. W. Staehling and F. L. Trowbridge. "Development of Normalized Curves for the International Growth Reference: Historical and Technical Considerations". American Journal of Clinical Nutrition 46, no 5 (1987): 736-748.

Donzelot, Jacques. The Policing of Families. Baltimore: The Johns Hopkins University Press, 1997.

Ehn, Billy, Orvar Lofgren and Richard Wilk. Exploring Everyday Life: Strategies for Ethnography and Cultural Analysis. Lanham: Rowman and Littlefield, 2016.

Foucault, Michel. Surveiller et Punir. Naissance de la prison. Paris: Gallimard, 1975. 
Francesconi, Chiara and Monica Raiteri (eds.). Pratiche Alimentari e Relazioni Sociali. Milan: FrancoAngeli, 2018.

Frauenfelder, Arnaud. "Consommations de viande, distinctions et régulations sociales". Carnets de bord 15 (2008): 60-62.

Freckelton, Ian. "Food Law: Challenges and Future Directions". Deakin Law Review 14, no 2 (2009): $219-232$. https://doi.org/10.21153/dlr2009vol14no2art142

Fucillo, Antonio (ed.). Diritto, Religioni, Culture: Il fattore religioso nell'esperienza giuridica. Turin: Giappichelli Editore, 2017.

Gonzalez, Carmen G. "Food Justice: An Environmental Justice Critique of the Global Food System". In International Environmental Law and the Global South, edited by Shawkat Alam, Sumudu Atapattu, Carmen G. Gonzalez and Jona Razzaque. Cambridge: Cambridge University Press, 2015.

Gotkin, Kevin. "The Norm and the Pathological”. Disability Studies Quarterly 36, no 1 (2016). http://dx.doi.org/10.18061/dsq.v36i1.4281

Graham, Rebekah, Darrin Hodgets and Ottilie Stolte. "Dual-Heritage Households: Food, Culture, and Re-Membering in Hamilton, New Zealand”. International Review of Social Research 6, no 1 (2006): 4-14. https://doi.org/10.1515/irsr2016-0002

Greenebaum, Jessica and Brandon Dexter. "Vegan Men and Hybrid Masculinity". Journal of Gender Studies 27, no 6 (2018): 637-648. https://doi.org/10.1080/09589236.2017.1287064

Hacking, Ian. Historical Ontology. Cambridge, MA: Harvard University Press, 2002.

Hammarberg, Thomas. "The Principle of the Best Interests of the Child-What It Means and What It Demands from Adults". Speech, Council of Europe, Strasbourg, 30 May 2008. https://rm.coe.int/16806da95d

Holm, Lotte, Marianne Pipping Ekstrom, Sara Hach and Thomas Boker Lund. "Cooking and Gender". In Everyday Eating in Denmark, Finland, Norway and Sweden, edited by Jukka Gronow and Lotte Holm, 123-140. London: Bloomsbury, 2008.

Johnston, Josée and Shyon Baumann. Foodies. Democracy and Distinction in the Gourmet Foodscape. New York/London: Routledge, 2015.

King, Margaret L. "Concepts of Childhood: What We Know and Where We Might Go". Renaissance Quarterly 60, no 2 (2007): 371-407.

Kittler, Pamela Goyan and Kathryn Sucher. Food and Culture in America. New York: West/Wadswort, 1998.

Labarre, Mathieu de. "Les trois dimensions de l'expérience alimentaire du mangeur: l'exemple du Sud-Ouest français". Anthropology of Food S1 (2001). https://journals.openedition.org/aof/1206

Lamarque, Elisabetta. Prima i Bambini. Il principio dei best interests of the child nella prospettiva costituzionale. Milan: FrancoAngeli, 2016.

Lindsay, Jo and JaneMaree Maher. Consuming Families: Buying, Making, Producing Family Life in the 21st Century. Abingdon: Routledge, 2013.

Maurer, Donna and Jeffery Sobal. Eating Agendas. Food and Nutrition as Social Problems. New York: Aldine de Gruyter, 1995.

Mayall, Berry. "The Sociology of Childhood in Relation to Children's Rights". The International Journal of Children's Rights 8 (2000): 243-259. https://doi.org/10.1163/15718180020494640

Mohr, Richard. "Subjects and Objects: Law and the Material in the Anthropocene". 'Linking Generations for Global Justice' International Congress, International Institute for the Sociology of Law, Oñati, Spain, 19-21 June 2019.

Mohr, Richard and Nadirsyah Hosen. "Crossing Over: Hosts, Guests and Tastes on a Sydney Street". Law Text Culture 17, no 1 (2014): 100-128.

Moutinho, Ana, Nélia F. Costa, Domingas Assunção, Edite Spencer, Verónica Tubal, Maurílio Gaspar and Anicete Cavaco. "Raquitismo Carencial: uma doença da modernidade?". Acta Pediátrica Portuguesa 46, no 1 (2015): 54-59.

Muller, Benjamin J. "Governmentality and Biopolitics". https://oxfordre.com/internationalstudies/internationalstudies/view/10.1093/acrefore/9780190846626.001.0001/acrefore9780190846626-e-50

Musio, Antonio. "Scelte alimentari dei genitori e interesse del minore". Rivista di Diritto Alimentare, XI, no 2 (2017): $4-14$.

Nath, Jemál. "Gendered Fare? A Qualitative Investigation of Alternative Food and Masculinities". Journal of Sociology 47, no 3 (2010): 261-278. https://doi.org/10.1177\%2F1440783310386828

Neuman, Nicklas, Karin Eli and Paulina Nowicka. "Feeding the Extended Family: Gender, Generation, and Socioeconomic Disadvantage in Food Provision to Children". Food, Culture \& Society 22, no 1 (2019): 45-62. https://doi.org/10.1080/15528014.2018.1547066

Niola, Marino. Non tutto fa brodo. Bologna: Il Mulino, 2012.

—. "Elogio del brunch". In Storie di Brunch, by Simone Rugiati. Milan: Rizzoli, 2010.

_. "Siamo quello che non mangiamo". La Repubblica. 26 May 2018. http://www.marinoniola.it/2018/05/26/siamo-quelloche-non-mangiamo-la-repubblica/

Oncini, Filippo. "Feeding Distinction: Economic and Cultural Capital in the Making of Food Boundaries". Poetics 73 (2019): 17-31. https://doi.org/10.1016/j.poetic.2019.02.002 
Pedroso, João and Patrícia Branco. "Mudam-se os tempos, muda-se a família. As mutações do acesso ao direito e à justiça de Família e das Crianças em Portugal”. Revista Crítica de Ciências Sociais, 82 (2008): 53-83.

Punch, Samantha, Ian McIntosh and Ruth Emond. "Children's Food Practices in Families and Institutions". Children's Geographies 8, no 3 (2010): 227-232. https://doi.org/10.1080/14733285.2010.494861

Sani, Ana Isabel. "Reflexões sobre infância e os direitos de participação da criança no contexto da justiça". E-cadernos ces 20 (2013): 75-89.

Santos, Boaventura de Sousa. As bifurcações da ordem. Revolução, cidade, campo e indignação. Coimbra: Almedina, 2017.

Sarat, Austin. "Editorial". Law, Culture and the Humanities, 10, no 2 (2014): 195.

Sicchiero, Gianluca. "La nozione di interesse del minore". Famiglia e diritto 1 (2015): 72-80.

Simões, Rita. "Representações do superior interesse da criança". 9-10 November, 2012. https://www.ces.uc.pt/coimbrac/pages/pt/comunicacoes-e-posters/216---rita-simoes.html

Skivenes, Marit and Line Marie Sørsdal. "The Child's Best Interest Principle across Child Protection Jurisdictions". In Human Rights in Child Protection, edited by A. Falch-Eriksen and E. Backe-Hansen, 59-88. Cham: Palgrave Macmillan, 2018.

Smil, Vaclav. "Worldwide Transformation of Diets, Burdens of Meat Production and Opportunities for Novel Food Proteins". Enzyme and Microbial Technology 30 (2002): 305-311.

Sobal, Jeffery. "Men, Meat, And Marriage: Models of Masculinity". Food and Foodways 13, no 1-2 (2005): 135-158. https://doi.org/10.1080/07409710590915409

United Nations International Children's Emergency Fund. The State of the World's Children 2019. Children, Food and Nutrition. Growing Well in a Changing World. (UNICEF, New York, 2019). https://data.unicef.org/resources/state-of-theworlds-children-2019/

van der Meulen, Bernd. “The Structure of European Food Law”. Laws no 2 (2013): 69-98. https://doi.org/10.3390/laws2020069

Vinther, Johan, Annalijn Conklin, Nicholas Wareham and Pablo Monsivais. "Marital Transitions and Associated Changes in Fruit and Vegetable Intake: Findings from the Population-Based Prospective Epic-Norfolk Cohort, UK". Social Science and Medicine 157 (2016): 120-126. https://doi.org/10.1016/j.socscimed.2016.04.004

Wall, Karin, Sofia Aboim and Vanessa Cunha (eds.). A vida familiar no masculino: negociando velhas e novas masculinidades. Lisbon: Comissão para a Igualdade no Trabalho e no Emprego, 2010.

Walton, Kathryn, Nicholas Horton, Sheryl Rifas-Shiman, Alison Field, S. Bryn Austin, Emma Haycraft, Andrea Breen and Jess Haines. "Exploring the Role of Family Functioning in the Association Between Frequency of Family Dinners and Dietary Intake Among Adolescents and Young Adults”. JAMA Network Open 1 no 7 (2018): 1-11. https://doi.org/10.1001/jamanetworkopen.2018.5217

Wooley, Kaitlin and Ayelet Fishbach. "A Recipe for Friendship: Similar Food Consumption Promotes Trust and Cooperation". Journal of Consumer Psychology 27, no 1 (2017): 1-10. https://doi.org/10.1016/i.jcps.2016.06.003

Wright, Jan, JaneMaree Maher and Claire Tanner. "Social Class, Anxieties and Mothers' Foodwork". Sociology of Health \& Illness 37, no 3 (2015): 422-436. https://doi.org/10.1111/1467-9566.12202

Zivkovic, Tanya, Megan Warin, Michael Davies and Vivienne Moore. "In the Name of the Child: The Gendered Politics of Childhood Obesity”. Journal of Sociology 46, no 4 (2010): 375-392. https://doi.org/10.1177\%2F1440783310384456 